\title{
EFFECT OF HEALTH RISK REDUCTION INTERVENTION TRAINING PROGRAM ON WASTE PICKERS' KNOWLEDGE AND WASTE HANDLING PRACTICES IN DUMP SITES IN OGUN STATE, NIGERIA
}

\author{
Tella Ayodeji ${ }^{1}$ and Amosu Ademola M. (Ph.D) ${ }^{2}$ \\ ${ }^{1}$ Department of Public Health, Babcock University, Ilishan-Remo, Ogun State, Nigeria \\ Email: ayotella1955@gmail.com \\ ${ }^{2}$ Department of Public Health, Babcock University, Ilishan-Remo, Ogun State, Nigeria \\ Email: amosua@babcock.edu.ng
}

Cite this article:

Tella A., Amosu A.M. (2021), Effect of Health Risk Reduction Intervention Training Program on Waste Pickers' Knowledge and Waste Handling Practices in Dump Sites in Ogun State, Nigeria. International Journal of Public Health and Pharmacology 1(2), 60-69. DOI: $10.52589 /$ IJPHPHHMNPG8E.

\section{Manuscript History \\ Received: 21 Oct 2021 \\ Accepted: 9 Nov 2021 \\ Published: 25 Nov 2021}

Copyright $\odot 2020$ The Author(s). This is an Open Access article distributed under the terms of Creative Commons AttributionNonCommercial-NoDerivatives 4.0 International (CC BY-NC-ND 4.0 ), which permits anyone to share, use, reproduce and redistribute in any medium, provided the original author and source are credited.
ABSTRACT: Objective: This study assessed the effect of health risk reduction training program on waste pickers' waste handling practices in dump sites in Ogun State, Nigeria. Methods: A quasiexperimental study was conducted among 60 waste pickers recruited by multistage sampling technique divided into intervention and control groups. There was a baseline assessment of waste handling practices in both the intervention and control groups using a structured interviewer-administered questionnaire. Thereafter, health risk reduction training was given via lectures and demonstrations. Three months after the intervention, another assessment of the same waste pickers was conducted with the same instrument. Waste handling practices and knowledge responses were measured on a 54-point rating scale and a 17-point rating scale respectively. Data was analyzed using IBM SPSS version 23 to generate descriptive and inferential results. Results: At the baseline, the waste pickers in the control group had a mean waste handling score of $17.80 \pm 6.89$ while the experimental group had a mean score of $17.97 \pm 5.47$. After the training program, there was a statistically significant increase in the mean waste handling score of the experimental group $(47.30 \pm 3.28 ; p=0.000)$ while there was no increase in the

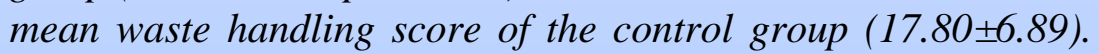
This significant increase in the mean waste handling score of the experimental group $(53.83 \pm 0.38 ; p=0.000)$ was also observed in a 3 month follow-up period. Conclusion/Recommendation: The health risk reduction training was effective in improving the waste handling practices of waste pickers. It is recommended that waste pickers should be trained on proper waste handling by the government.

KEYWORDS: Dumpsite, Health-risk Reduction, Knowledge, Waste-pickers, Waste-handling. 


\section{INTRODUCTION}

Nigeria, with an estimated 200 million people, accounts for $20 \%$ of the total population in subSaharan Africa (United Nations, 2019). Municipal solid waste generation has been on an increase due to waste generated daily by individuals in the country (Dlamini, Simatele, \& Kubanza, 2019). This rapid population growth, together with industrial activities, has led to an increase in the use of materials capable of producing hazardous wastes. Waste is invariably produced wherever human beings carry out economic activities and different materials are used. Such waste can be hazardous or non-hazardous. When waste is not properly handled, it can threaten the atmosphere, the water, soil, and living organisms (Ifeoluwa, 2019). The waste generation rate in Nigeria is estimated at $0.65-0.95 \mathrm{~kg} / \mathrm{capita} /$ day which gives an average of 42 million tonnes of waste generated annually. This is more than half of 62 million tonnes of waste generated in sub-Saharan Africa annually, and where and how to channel these wastes becomes a huge problem for the nation. Only $20-30 \%$ is collected and $70 \%$ are dumped in unsafe places (Bakare, 2021; Dlamini, Simatele, \& Kubanza, 2019). It is common to find large heaps of garbage lying in a disorganized manner in and around cities due to the inability of municipal corporations to handle large quantities of waste (Bakare, 2021).

Disposal of solid waste at a landfill site is the primary disposal method used in most developing countries including Nigeria (Mathema, Shadung, \& Chris, 2017). Most of the wastes dumped are decomposable materials while the remaining recyclables are picked up by waste pickers (Bhugra \& Biswa, 2015). Sarka (2003) described them as those who make a living by collecting and selling recyclable materials out of municipal solid waste. Waste picking is a widespread and regular activity in nearly all cities in developing countries. Some waste pickers work at a single site that holds an abundance of waste, like dump sites and transfer stations. Others move from place to place, collecting materials from factories, offices, stores, schools, hospitals, and residential areas. Others work at dump sites, canals, and rivers where people dump their refuse (Janis, 2004). It is estimated that, worldwide, some two million individuals work informally as waste pickers. These people are the first to suffer the consequences of the inadequate management of solid wastes (Hoornweg \& Bhada-Tata, 2012). Their work results in waste separation, waste reuse, aiding recycling, and reducing pressure on the environment. They often do not wear any protective equipment; they therefore face great risks of injuries linked to the type of material they are collecting (Awopetu et al., 2014). These waste pickers are susceptible to injuries due to lack of the necessary personal protective equipment (PPE) and thus are faced with pitiable working conditions. Waste picking is therefore considered as a dangerous occupation (Araújo \& Tatiana, S., 2018). Some studies have proposed that protective gear such as clothing, gloves, and boots should be given to waste pickers to reduce pathogenic infections and increase their effectiveness (Ojeda-Benitez et al., 2002; Hina \& Devadas, 2008; Wilson, Velis, \& Cheeseman, 2006). Hence this study determines the effect of health risk reduction training on waste pickers' knowledge and waste handling practices in dump sites in Ogun State, Nigeria.

\section{MATERIALS AND METHODS}

The present study was carried out at Oke-Saje dumpsite and Koto-Ajala dump site in Ogun State. A quasi-experimental study design was applied to assess the effect of health risk reduction training on waste pickers' knowledge and waste handling practices. 
For the intervention program, 60 waste pickers were chosen randomly; $50 \%$ of them (30) were subjected to the pre-developed health risk training program (Intervention group) while the other $50 \%$ (30) were not (designated as Control group). Both groups were subjected to a pre-test and two post-tests, one immediately after the end of the intervention program, and the other, three months later. A predesigned and pre-coded interviewer-administered questionnaire was filled by the waste pickers in order to assess their waste handling practices.

The knowledge question on solid waste handling consists of seventeen questions. This evaluates the scavenger's knowledge of solid waste handling/exposure, and health effects of waste. It comprises multiple choice dichotomous of Yes/No. The knowledge questions were scored as follows: score "1" for a correct answer, score "0" for an incorrect answer and for 'don't know'. The total mean knowledge score was calculated for each question by summing up every category; total scores were calculated $(17 \times 1=17)$ ranging from $0-17$ points, adjusted out of $100(0 \%-100 \%)$ and were graded as follows: poor knowledge (0-8.5 points) and good knowledge (8.6-17 points).

The waste handling practice questions were scored as follows: score "2" for 'every time' answer, score "1" for 'sometimes' answer, and score "0" for 'never' answer.

The total mean waste handling score was calculated for each question by summing up every category, and total scores were calculated $(27 \times 2=54)$ ranging from $0-54$ points; they were then adjusted out of $100(0 \%-100 \%)$ and graded as follows: Good level of waste handling practice $(28-54$ points $)>50 \%$, and Poor level of waste handling practice $(0-27$ points $) \leq 50 \%$.

\section{Intervention Program}

An intervention program was designed according to the results of the pre-test. The program was tailored according to the needs of the waste pickers under study. The training manuals were prepared, reviewed and tested before use.

Four training modules were delivered over four weeks; the participants' attended the sessions in the morning from 10:00 a.m. to 11:30 a.m., once weekly. The methods used in the intervention program included lectures and demonstrations. The contents of the four sessions of the health training intervention program were as follows: environmental effect of solid waste, importance of preventing exposure to solid waste from entering the body, diagnosis, first aid, and treatment of diseases related to waste handling and disposal. There is also a demonstration on the use of PPE and personal hygiene.

\section{Ethical Issues and Confidentiality}

A written approval from Babcock University Health Research Committee and Ogun State Ministry of Environment (BUHREC) was obtained, indicating that an academic research study within Oke-Saje and Koto-Ajala dumpsites was to be done. The sample participants agreed to participate voluntarily in the study and were informed of the date of the program. Confidentiality was ensured throughout the study period and only code numbers were used instead of the participant's names. 


\section{Statistical Analysis}

Data were collected, revised, coded and fed to the statistical software IBM SPSS (Statistical Package for the Service Solution) version 23. Descriptive statistics including frequency distribution and percentages were performed. For quantitative variables, mean and standard deviation were calculated. Inferential statistics include $t$-test, and Cohen d effect size. The two tailed tests, alpha error of 0.05 , and p-value less than 0.05 were considered significant.

\section{RESULTS}

\section{Socio-Demographic Characteristics of the Waste Pickers}

The mean ages of the waste pickers in the intervention and the control groups were $25.27 \pm 4.90$ and 29.90 \pm 4.44 respectively. Their ages ranged from 18 to 43 years. Most of the participants in the two groups were within the 24-29 age brackets. All the participants in the two groups were males. Half of the participants in the intervention group were married while $60 \%$ in the control group were married. Most of the participants in the two groups were of the Islamic faith, while only $16.7 \%$ and $33.3 \%$ of the participants were Christians in the experimental group and control group respectively. Fifty percent of the participants in the experimental group had no formal education with only $6.7 \%$ of them with tertiary education, while $20 \%$ of the participants in the control group had no formal education with only $3.3 \%$ of them with tertiary education. Most of the participants in the two groups lived in a temporary shelter in the dump site. Most of the participants in the two groups had been scavenging for between 56 years (See Table 1$)$.

\section{Baseline Knowledge and Waste Handling Practices of Waste Pickers}

The mean \pm SD scores for the waste pickers' level of knowledge on waste handling practices in the experimental and control groups were $7.17 \pm 1.64$ and $6.53 \pm 2.43$ respectively. Only $30 \%$ in the experimental group had good knowledge of waste handling practices while a much lower proportion $(16.7 \%)$ in the control group had good knowledge. When the waste pickers' mean scores of levels of knowledge on waste handling practices measured in this study were compared with the control and experimental groups at baseline, independent t-test computation showed that there was no significant difference $(P>0.05)$ (See Table 2).

Furthermore, the waste pickers' mean scores and standard deviations for the control and experimental groups were $17.97 \pm 5.47$ and $17.80 \pm 6.89$ respectively. All $(100 \%)$ of the participants in the intervention group had a low practice of waste handling while $93.3 \%$ of the control group had a low practice. When waste pickers' waste handling mean score measured in this study was compared with the control and intervention groups at the baseline, independent t-test computations showed no significant difference $(P>0.05)$ (See Table 2).

\section{The Effects of the Training Program on Waste Pickers' Knowledge and Waste Handling Practices}

The effects of the training program are summarized in Table 3. Overall, the intervention group showed a significantly higher mean knowledge score than the control group at immediate post intervention and at follow up period $(\mathrm{P}<0.05)$. The intervention group and control group had mean knowledge scores of $11.93 \pm 1.64$ and $7.17 \pm 1.64$ respectively at immediate post 
intervention. At the follow-up period, the intervention group had a mean knowledge score of $14.37 \pm 2.86$ while there was no increase in the mean knowledge score of the control group

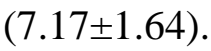

Furthermore, the waste pickers' waste handling practices mean score for the experimental group increased significantly at immediate post intervention (47.30 \pm 3.28$)$ compared with the control group mean score $(17.80 \pm 6.89 ; \mathrm{p}<0.05)$. Also, there was a significant increase in waste handling practices of the intervention group compared with the control group at follow-up period $(\mathrm{p}<0.05)$.

\section{Comparison of the Effect of the Mean Score of Waste Pickers' Knowledge and Waste Handling Practices between the Baseline and the Follow-up Period}

Evaluating the impact of the intervention on waste pickers' level of knowledge on waste handling practices, by comparing the baseline and the three months follow-up means scores for the experimental group using paired sample t-test, revealed that there was a statistically significant difference in the mean scores and the effect size computed, indicating that the magnitude of the difference in mean scores between the baseline and the 8th week follow-up period was significant. The intervention group had an effect size of -3.141 with a p-value of 0.000 . However, the control group had no effect size since there was no difference in the mean scores between the baseline and follow-up period ( $E S=0.000)$ (See Tables 4 and 5).

In addition, evaluating the impact of the intervention on waste pickers' risk waste handling practices, by comparing the baseline and the follow-up mean scores for the experimental group using paired sample t-test, revealed that there was a statistically significant difference in the mean scores and the effect size computed, indicating that the magnitude of the difference in mean scores between the baseline and the follow-up period was significant. The intervention group had an effect size of -9.407 with a p-value of 0.000 . However, the control group had no effect size since there was no difference in the mean score between the baseline and the followup period $(\mathrm{ES}=0.000)$ (See Table 4$)$.

\section{DISCUSSION}

This study evaluated the effect of health- risk reduction intervention training program on waste pickers' knowledge and waste handling practices in dump sites in Ogun State, Nigeria.

The study results revealed no differences between religion, educational level, marital status and the length of time of working as a waste picker. Most scavengers were married and had a primary school education. Some rented rooms or had temporary shelters at the dump sites. This is similar to another study conducted in Thailand by Sunthonchai (2006) in terms of the demographics, characteristics, and working hours. However, the study revealed a difference in age and where the waste pickers lived. This finding is not in line with the findings of Sunthonchai (2006). The difference in findings may be because of different study locations.

Furthermore, this study shows that the baseline data on knowledge and waste handling practices of the waste pickers in the experimental group and the control group had no significant differences. This explains that the experimental and control group were matched 
before the intervention. This finding is similar to the finding of Thirarattanasunthon et al. (2012).

The present study revealed a highly significant improvement in the waste pickers' knowledge of waste handling as compared with the control group. This indicates that the training program had a very good effect. This is due to the content of the training intervention program. The findings of the present study are supported by Thirarattanasunthon et al. (2012) and Kumar, Somrongthong, and Shaikh (2015).

Concerning the waste pickers' waste handling, this study revealed that there is a significant increase in the waste pickers' waste handling practice after the training program. This finding is similar to the findings of Thirarattanasunthon et al. (2012) and Enwere and Diwe (2014).

\section{CONCLUSION}

The health risk reduction training led to a significant increase in the waste pickers' knowledge of waste handling, and an improvement in their waste handling practices in the intervention group when compared with the control group. This implies that waste pickers exposed to solid waste at dump sites should be trained on how to follow safety recommendations concerning routine work at these sites to help reduce health risks.

\section{Acknowledgement}

We wish to acknowledge the waste pickers that took part in this study for their immense support.

\section{REFERENCES}

Araújo, N.C, \& Tatiana, S.(2018). A descriptive study of work ability and health problems among Brazilian recyclable waste pickers. Journal of Community Health, 43(2), 366371.

Awopetu, M.S., Awopetu, R.G., Sample, E.D., Olufiropo, A.O., Awokola, S., Fullen, M.A., \& Hammond, F.N. (2014). Municipal solid waste management and the role of wastepickers in Nigeria. International Journal of Education Research, 2: 1-12.

Bakare, W. (2021) Solid Waste Management in Nigeria. Bio-Energy Newsletter 5: 68-72.

Bhugra, S. \& Biswas, S. (2015). Assessment of health hazardous of waste-pickers using intelligent system. International Journal of Emerging Engineering Research and Technology 3(9): 41-44.

Dlamini, S,. Simatele, M., \& Kubanza, N. (2019). Municipal solid waste management in South Africa: From waste to energy recovery through waste-to-energy technologies in Johannesburg. Local Environment, 24: 249-257.

Hina, Z., \& Devadas, V. (2008).Urban solid waste management in Kanpur: Opportunities and perspectives. Habitat International, 32, 58-73.

Hoornweg, D., \& Bhada-Tata, P. (2012). What a waste: a global review of solid waste management 
Ifeoluwa, O.B. (2019). Harmful effects and management of indiscriminate solid waste Ddsposal on human and its environment in Nigeria: A Review. Global Journal Research and Review, 6(1); 1-4

Janis B. (2004). Tool kit on Social Assessment and Public Participation in Municipal Solid Waste Management. Retrieved from http://www.worldbank.org/urban/uswm/socialassesstool.pdf

Kumar, R., Somrongthong, R., \& Shaikh, B.T. (2015). Effectiveness of intensive healthcare waste management training model among health professionals at teaching hospitals of Pakistan: a quasi-experimental study. BMC Health Serv Res 15, 81. https://doi.org/10.1186/s12913-015-0758-7

Mathema, M., Shadung J., \& Chris L. (2017).A Review of the Working Conditions and Health Status of Waste Pickers at Some Landfill Sites in the City of Tshwane Metropolitan Municipality, South Africa. Advances in Applied Science Research, 8(3):90-97

Ojeda-Benitez, S., Armijo-de-Vega, C., \& Ramirez-Bareto, M.E. (2002). Formal and informal recovery of recyclables in Mexicali, Mexico: Handling alternatives. Resource Conservation. Recycle, 34: 273-288.

Sarkar, P (2003). Solid waste management in Delhi - A social vulnerability study. In: Bunch, MJ, Suresh, M, Kumaran, TV (eds) Proceedings of the third international conference on environment and health, Chennai, India, 15-17 December 2003. Chennai: Department of Geography, University of Madras and Faculty of Environmental Studies, York University, pp.451-464.

Sunthonchai, S., Phoolpoksin, W.(2006). Health and Environment Protection of Waste Picker and related Labors. Complete report RA427.8, 2006. [database on the Internet waste picker and related labors 2006]. Available from: http//: www.google.co.th/\#hl=th\&output=search\&sclient=psy-ab $\& q=$ sarisak\%2Cwaste+picker\&oq=sarisak\%2Cwaste+picker\&gs_l=

Thirarattanasunthon, P., Siriwong, W., Robson, M., \& Borjan, M. (2012). Health risk reduction behaviors model for waste-pickers exposed to solid waste in municipal dump sites in Nakhon Ratchasima Province, Thailand. Risk management and healthcare policy, 5, 97.

United Nations Population Reports (2019). World population prospects. https://population.un.org/wpp/Publications/Files/WPP2019_Highlights.pdf

Wilson, D.C., Velis, C., \& Cheeseman, C.(2006). Role of informal sector recycling in waste management in developing countries. Habitat International 30; 797-808. 


\section{APPENDIX}

Table 1: Socio-Demographic Characteristics of Waste Pickers in the Experimental and Control Groups

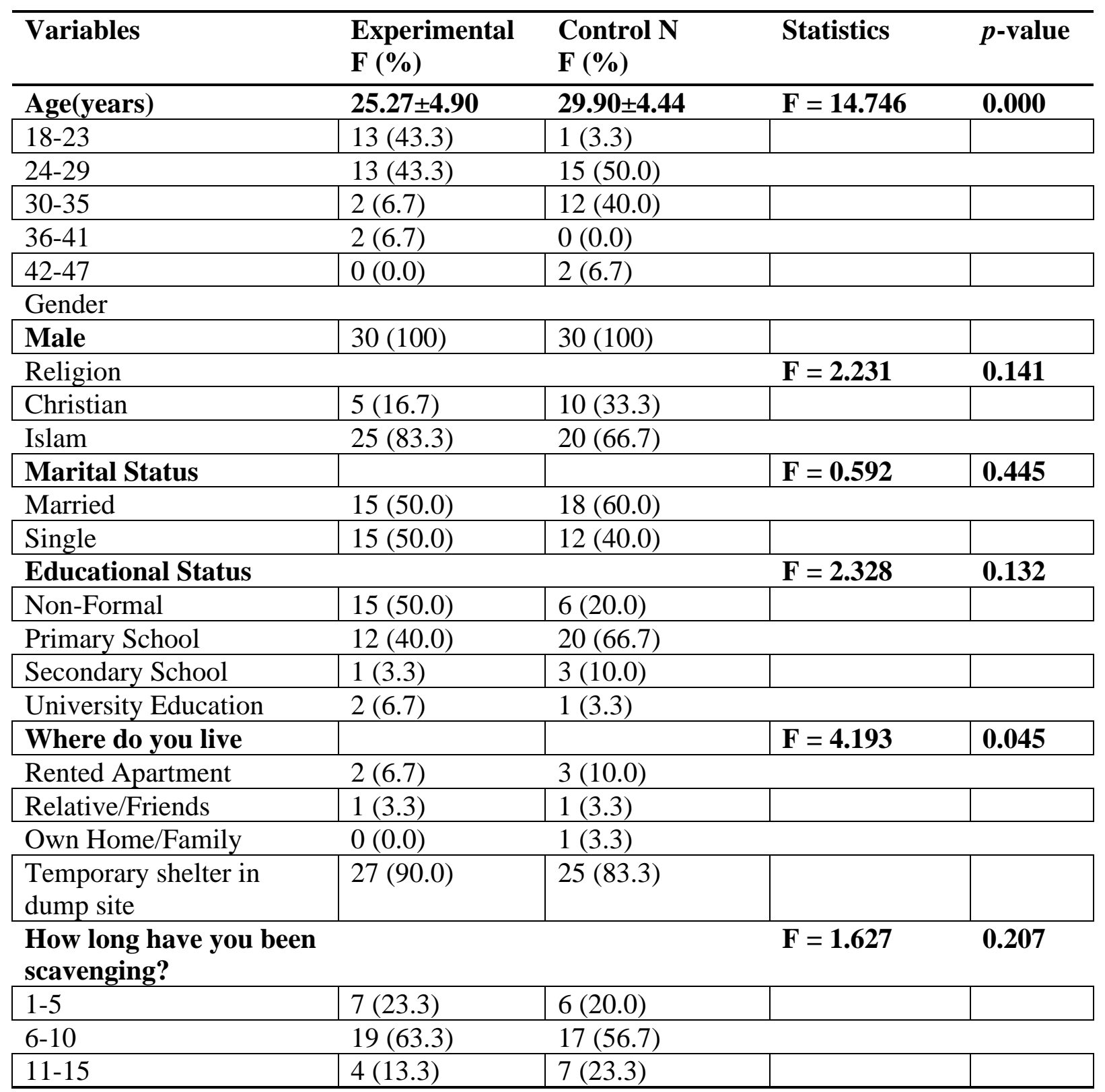


International Journal of Public Health and Pharmacology

Volume 1, Issue 2, 2021 (pp. 60-69)

Table 2: Baseline Knowledge and Waste Handling Practices of Waste Pickers

\begin{tabular}{|c|c|c|c|c|}
\hline $\begin{array}{l}\text { Knowledge of Waste Handling } \\
\text { Practices }\end{array}$ & $\begin{array}{l}\text { Experimenta } \\
\text { l F }(\%)\end{array}$ & $\begin{array}{l}\text { Control F } \\
(\%)\end{array}$ & $\begin{array}{l}\text { Statistic } \\
\mathrm{s} \\
\mathrm{t}=\text { value }\end{array}$ & $p$-value \\
\hline \multicolumn{5}{|c|}{ Measured on a 17-point Rating Scale } \\
\hline Poor (0-8.5) & $21(70.0)$ & $25(83.3)$ & & \\
\hline Good (8.6-17) & $9(30.0)$ & $5(16.7)$ & & \\
\hline Mean \pm SD & $7.17 \pm 1.64$ & $6.53 \pm 2.43$ & 1.18 & 0.24 \\
\hline \multicolumn{5}{|l|}{ Waste Handling Practices } \\
\hline \multicolumn{5}{|c|}{ Measured on a 54-point Rating Scale } \\
\hline Poor & $30(100.0)$ & $28(93.3)$ & & \\
\hline Good & $0(0.0)$ & $2(6.7)$ & & \\
\hline Mean \pm SD & $17.97 \pm 5.47$ & $17.80 \pm 6.89$ & 0.104 & 0.918 \\
\hline
\end{tabular}

Table 3: The Effects of the Training Program on Waste Pickers' Knowledge and Waste Handling Practices

\begin{tabular}{|c|c|c|c|c|c|c|}
\hline \multirow[t]{2}{*}{ Knowledge } & \multicolumn{3}{|c|}{ Experimental Group } & \multicolumn{3}{|c|}{ Control Group } \\
\hline & $\begin{array}{l}\text { Post } \\
\text { Intervention }\end{array}$ & Follow-up & $p$-value & $\begin{array}{l}\text { Post } \\
\text { Intervention }\end{array}$ & Follow-up & $\begin{array}{l}p \text { - } \\
\text { value }\end{array}$ \\
\hline Poor & $0(0.0)$ & $0(0.0)$ & 0.000 & $25(83.3)$ & $25(83.3)$ & N/A \\
\hline Good & $30(100)$ & $30(100)$ & & $5(16.7)$ & $5(16.7)$ & \\
\hline Mean \pm SD & $11.93 \pm 1.64$ & $14.37 \pm 2.86$ & & $6.53 \pm 2.43$ & $6.53 \pm 2.43$ & \\
\hline \multicolumn{7}{|c|}{$\begin{array}{l}\text { Waste Handling } \\
\text { Practices }\end{array}$} \\
\hline Poor & $0(0.0)$ & $0(0.0)$ & 0.00 & $28(93.3)$ & $28(93.3)$ & N/A \\
\hline Good & $30(100)$ & $30(100)$ & & $2(6.7)$ & $2(6.7)$ & \\
\hline Mean \pm SD & $47.30 \pm 3.28$ & $53.83 \pm 0.38$ & & $17.80 \pm 6.89$ & $17.80 \pm 6.89$ & \\
\hline
\end{tabular}

*N/A: Cannot be computed 
Table 4: Comparison of the Effect of the Mean Score of Waste Pickers' Knowledge and Waste Handling Practices between the Baseline and the Follow-up Period

\begin{tabular}{|l|l|l|l|l|l|l|l|l|}
\hline \multirow{2}{*}{ Knowledge } & \multicolumn{3}{|c|}{ Experimental Group } & \multicolumn{3}{c|}{ Control Group } \\
\cline { 2 - 10 } & Baseline & Follow-up & $\boldsymbol{p}$-value & $*$ ES & Baseline & Follow-up & $\boldsymbol{p}$-value & $*$ ES \\
\hline Poor & $21(70.0)$ & $0(0.0)$ & 0.000 & 3.14 & $25(83.3)$ & $25(83.3)$ & N/A & 0.000 \\
\hline Good & $9(30.0)$ & $30(100)$ & & & $5(16.7)$ & $5(16.7)$ & & \\
\hline Mean \pm SD & $7.17 \pm 1.64$ & $14.37 \pm 2.86$ & & & $6.53 \pm 2.43$ & $6.53 \pm 2.43$ & & \\
\hline $\begin{array}{l}\text { Waste } \\
\text { Handling } \\
\text { Practices }\end{array}$ & & & & & & & & \\
\hline Poor & $30(100.0)$ & $0(0.0)$ & 0.00 & 9.40 & $28(93.3)$ & $28(93.3)$ & N/A & 0.000 \\
\hline Good & $0(0.0)$ & $30(100)$ & & & $2(6.7)$ & $2(6.7)$ & & \\
\hline Mean \pm SD & $17.97 \pm 5.47$ & $53.83 \pm 0.38$ & & & $17.80 \pm 6.89$ & $17.80 \pm 6.8$ & & \\
\hline
\end{tabular}

*ES: Effect size

Table 5: T- Test Evaluating the Impact of the Intervention on Waste Pickers' Level of Knowledge and Waste Handling Practices by Comparing the Baseline and the Followup of the Experimental Group

\begin{tabular}{|c|c|c|c|c|c|c|c|c|}
\hline \multirow[t]{3}{*}{ Variable } & \multicolumn{5}{|c|}{ Paired Differences } & \multirow[b]{3}{*}{$\mathbf{t}$} & \multirow[b]{3}{*}{ Df } & \multirow{3}{*}{$\begin{array}{l}\text { Sig. } \\
(2- \\
\text { tailed })\end{array}$} \\
\hline & \multirow[t]{2}{*}{ Mean diff } & \multirow[t]{2}{*}{$\begin{array}{l}\text { Std. } \\
\text { Deviation }\end{array}$} & \multirow{2}{*}{$\begin{array}{l}\text { Std. } \\
\text { Error } \\
\text { Mean }\end{array}$} & \multicolumn{2}{|c|}{$\begin{array}{l}95 \% \text { Confidence Interval } \\
\text { of the Difference }\end{array}$} & & & \\
\hline & & & & Lower & Upper & & & \\
\hline $\begin{array}{l}\text { Baseline } \\
\text { Knowledge } \\
\text { Follow-up } \\
\text { Knowledge } \\
\end{array}$ & -3.60000 & 4.11776 & .53160 & -4.66373 & -2.53627 & -6.772 & 59 & 0.000 \\
\hline $\begin{array}{l}\text { Waste } \\
\text { Handling } \\
\text { Practice } \\
\text { Follow-up } \\
\text { Period }\end{array}$ & -17.9333 & 18.51510 & 2.39029 & -22.71629 & -13.15038 & -7.503 & 59 & 0.000 \\
\hline
\end{tabular}

